
SHORT COMMUNICATIONS

\title{
AUTOMATIC AUTONOMOUS LIGHT TRAPS AND THEIR USAGE FOR THE QUANTITATIVE ACCOUNTINGON EXAMPLE OF HAWKMOTHS OF KYRGYZSTAN (LEPIDOPTERA: SPHINGIDAE)
}

\author{
Stanislav K. Korb \\ Nizhny Novgorod Division of Russian Entomological Society, Russia \\ e-mail: stanislavkorb@list.ru
}

Received: 11.11.2017

\begin{abstract}
The quantitative accounting of Sphingidae of Kyrgyzstan using automatic autonomous light traps is presented. 16 species with nocturnal activity were recorded, four of them are most numerous, eight are of average abundance, one is a migrant and three are rare. Two species are proposed for inclusion in the Red Data Book of Kyrgyzstan (Sphingonaepiopsis kuldjaensis, Proserpinus proserpina).
\end{abstract}

Key words: hawkmoths, light traps, quantitative accounting, Red Data Book of Kyrgyzstan, Sphingidae

\section{Introduction}

The Lepidoptera fauna of Kyrgyzstan is rich and unique. Butterflies are traditionally studied better than moths: a lot of faunistic and systematic works have been published (e.g. Korb, 2012, 2013, 2015, 2017; Tshikolovets, 2005). The moths fauna of this country has not been studied well; most of the data about this fauna can be extracted from the «Cadastre of the genetic diversity of Kyrgyzstan» (Milko, 1996) as far as from some recently published papers (Kaila et al., 1996; Korb et al., 2016; Schintlmeister, 2008). The Sphingidae fauna of this country has been studied at the same level as most of the other moths: no special issue was published about it. Basically, the only source for the hawkmoth fauna of Kyrgyzstan is the Internet-project of A.R. Pittaway entitled «Sphingidae of the Western Palearctic», http:// tpittaway.tripod.com/sphinx/.

The light trapping is quite an old and very effective tool for biodiversity research. It was widely used by Russian researchers starting from the middle part of the last century (Bogush, 1951; Mazokhin-Porshnyakov, 1958; Gornostaev, 1961; Matalin, 1996); its usage for the quantitative accounting of nocturnal Lepidoptera is very well known (Dubatolov, 2012). The light trapping is used for studies of some aspects of the hawkmoths ecology, including fauna, seasonality, flight period, etc. (Beck,
Linsenmair, 2006; Duarte, Schlindwein, 2008; Vieira et al., 2015).

The quantitative analysis is the only tool to determine the rarity of species; the reason to use the quantitative analysis is its objectivity. Before the introduction of automatic autonomous light traps (hereinafter - traps) scientists used white canvas sheets with powerful UVlamps (usually about 160-250W, sometimes more powerful). The use of such devices has one but very important drawback: the researcher has to continuously register the specimens, which come to the light. Of course, not all the incoming species get recorded, and of course, some of them draw a little bit more attention than others. The traps are totally different in this respect: they catch everything and they work automatically.

The availability of quantitative data for many families of Lepidoptera, especially those with nocturnal activity, is very poor. For Middle Asia investigations of this kind do not exist. During 2015-2017, I processed a large number of light catches from the territory of Kyrgyzstan. This paper is devoted to the results of the quantitative accounting of the moth family Sphingidae (hawkmoths).

\section{Material and Methods}

The main tool of my research is the trap (Fig. 1). 


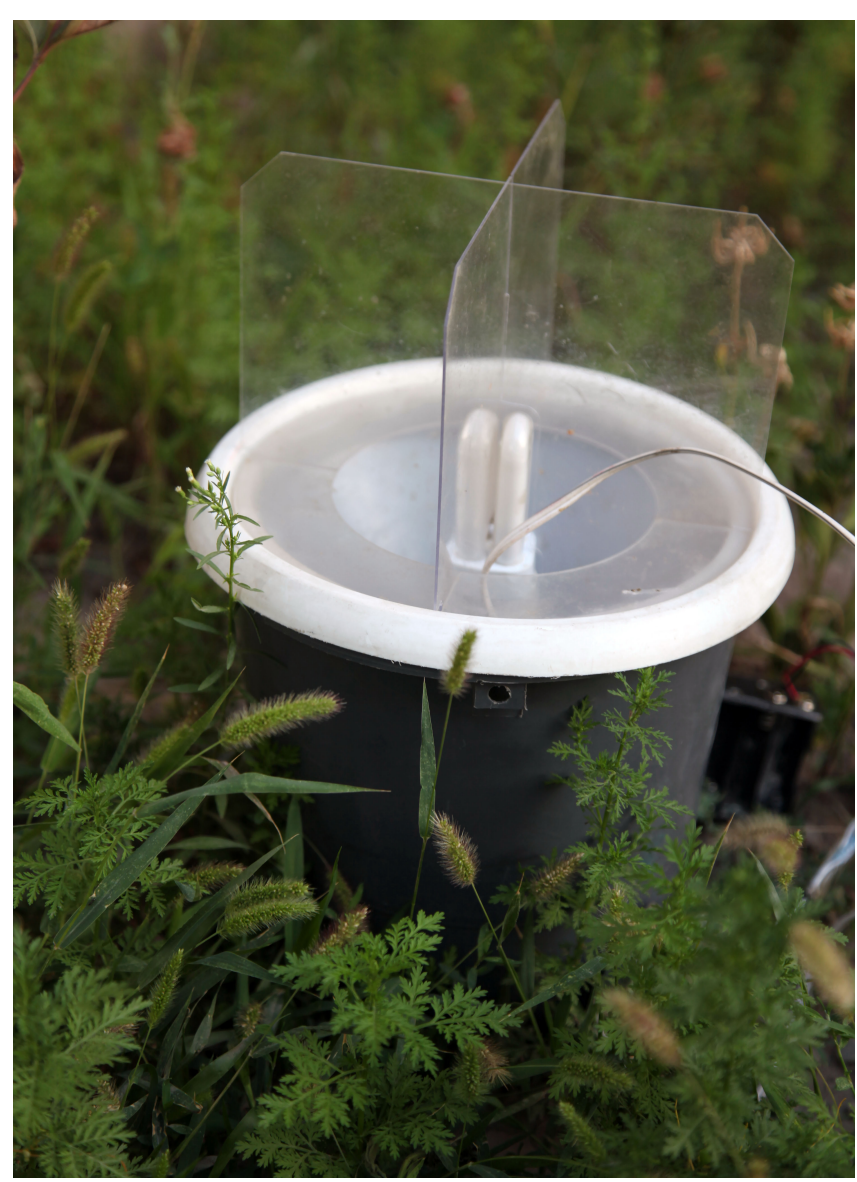

Fig. 1. The light trap.

Its construction is based on a plastic bucket into which a fast-working poison is placed (I use tetrachloroethane) as well as some layers of the cell-carton (I use the eggs carton pieces). The bucket is equipped with the attractor (UV-lamp) and a trapping device. The last one contains a wide-mouthed funnel and three plastic shields (one is rounded and two are rectangular). An electric circuit that consists of the power supply (I am using the battery block of eight AA-batteries with voltage of $1.5 \mathrm{~V}$ each, in total $12 \mathrm{~V}$ ), the inverter (it transforms $12 \mathrm{~V}$ to $220 \mathrm{~V}$ ) and the automatic electric switch (I use the photocell) powers the lamp.

The trap is working in the following way. The poison is placed inside by a small portion $(30-50 \mathrm{~g})$. The batteries are inserted into the battery block. Then the trapping device and UVlamp are placed on the bucket. The trap is now ready for use. It is placed into the habitat that is to be investigated. Two types of the UV-lamps can be used: black UV and white UV, their light powers vary between 8 and $32 \mathrm{~W}$. When darkness comes, the photocell will enable the trap; when the sunlight appears, the same device will disable the trap.
Depending on the amount of poison and on the battery quality, the trap can work 1-3 nights but I recommend taking the collected material after every night just because the trap is collecting not only moths but also Orthopteroid, Coleopteroid, Hymenopteroid and other insects with night activity. These insects can be resistant to the poison and thus they will damage or even destroy the collected material.

The working area of the single trap varies depending on the lamp power between 50 and $350 \mathrm{~m}$; when two types of UV-light (black and white) are combined, it is possible to investigate a reasonably large area with such traps. In addition, the traps can be powered not only from the batteries but also from gasoline electric generators, but then they lose their autonomy. The moths were collected not only from the traps, but also from the area around the traps because many species of Sphingidae prefer to stay on the border of the light spot.

Our material was collected in the following localities of Kyrgyzstan (fig. 2):

Ala-Archa. $42^{\circ} 39^{\prime}$ N, 7430' E. Kirghiz Mts., National Park Ala-Archa. Degree of disturbance: minimal, protected area.

Ala-Too. 4247'26.35" N, 7441'46.12" E. Kirghiz Mts., Bishkek environs, 1.2 S of Ala-Too village. Degree of disturbance: high (overgrazing, burning of grass, garbage dump, etc.).

Archaly. $39^{\circ} 50.370^{\prime} \mathrm{N}, 7^{\circ} 19.593^{\prime}$ E. Alai Mts., 9,6 km NW of Kichi-Karakol settlement. Degree of disturbance: medium (haymaking, irrigation).

Karakol. $42^{\circ} 11.399^{\prime} \mathrm{N}, \quad 74^{\circ} 03.193^{\prime}$ E. Dzhumgaltoo Mts., Sary-Kaiky massif, right shore of West Karakol. Degree of disturbance: minimal, protected area.

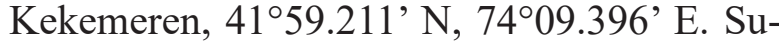
usamyrtoo Mts., Kekemeren river valley. Degree of disturbance: low (moderate grazing).

Kok-Jar. 4248'41.34" N, 74³8'57.98" E. Kirghiz Mts., Bishkek environs, Kok-Jar settlement. Degree of disturbance: high (anthropocenosis).

Koro-Goo. 41 ${ }^{\circ} 31.303^{\prime}$ N, 7445.824' E. Moldo-Too Mts., Koro-Goo Pass. Degree of disturbance: medium (overgrazing).

Sarban. 4247'55.47" N, 74³0'45.70" E. Kirghiz Mts., Bishkek environs, Sarban settlement. Degree of disturbance: high (anthropocenosis).

Urumbash. $41^{\circ} 20^{\prime} \mathrm{N}, 73^{\circ} 30^{\prime}$ E. Fergansky Mts., eastern slope, 2-3 km NNE of Urumbash Pass. Degree of disturbance: medium (haymaking, moderate grazing). 


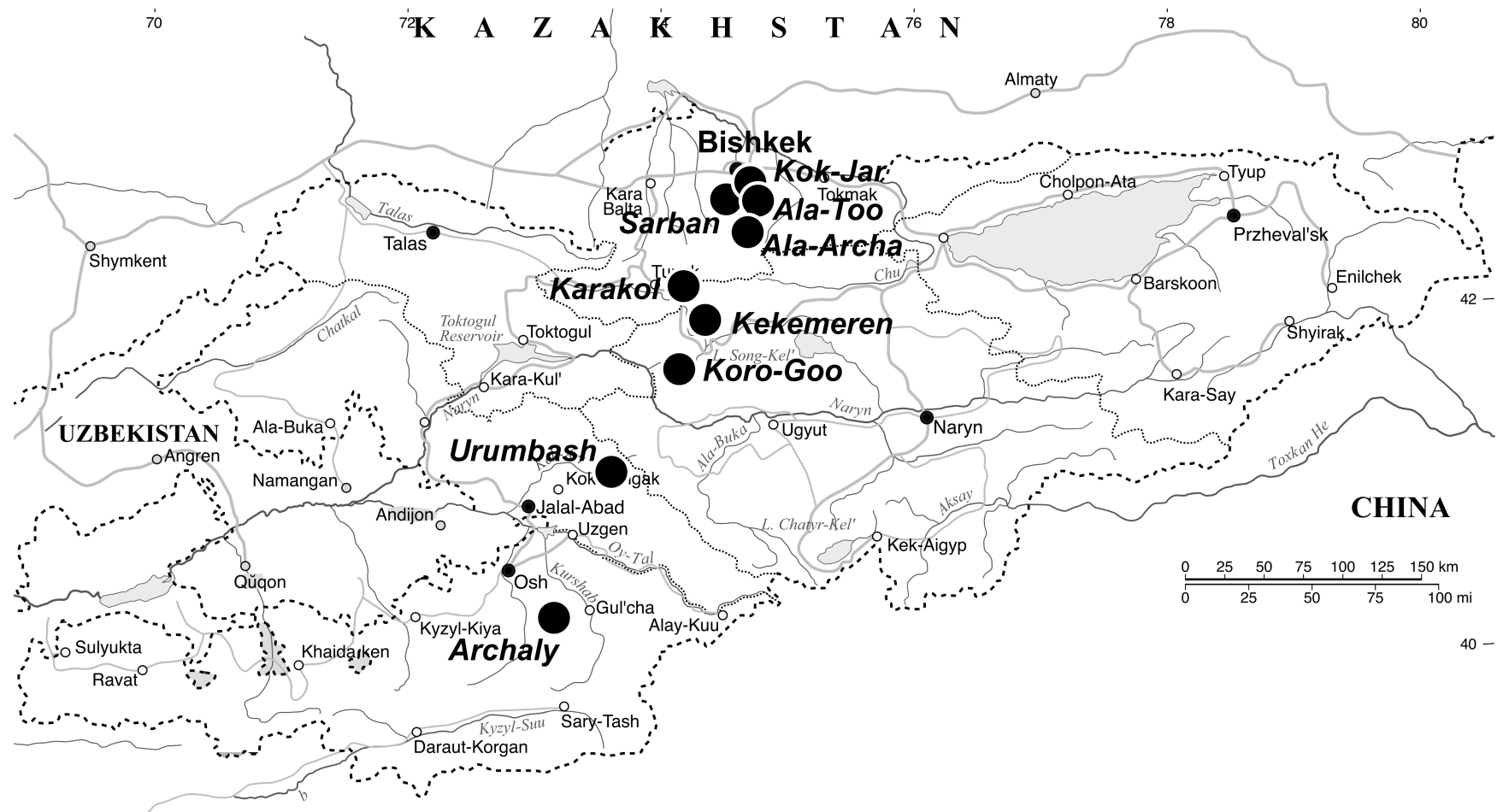

Fig. 2. The quantitative accounting locations within Kyrgyzstan.

Within each of the selected localities, the research work was conducted simultaneously by the traps equipped with black and white UV-lamps. The average amount of used traps in each locality is three; the total number of records within one locality is 30 . Investigations have been carried out between May and August in 2015-2017.

The system of hawkmoths used in this paper follows Derzhavets (1984).

\section{Results}

In total, between 2015-2017 2185 specimens of 16 hawkmoths species $(72.7 \%$ of the fauna) have been recorded (Table 1). The most numerous species are: Agrius convolvuli (Linnaeus, 1758), Deilephila porcellus (Linnaeus, 1758), Hyles gallii (Rottemburg, 1775) and H. livornica (Rottemburg, 1775) (18.2\% of the fauna). The rarest species are: Sphingonaepiopsis kuldjaensis (Graeser, 1892), Rethera komarovi Christoph, 1885, Proserpinus proserpina (Pallas, 1772), H. nicaea (de Prunner, 1798) (another $18.2 \%$ of the fauna). The species with average abundance are $31.2 \%$ of fauna: Smerinthus kindermannii Lederer, 1852, Laothoe populi (Linnaeus, 1758), Theretra alecto (Linnaeus, 1758), Deilephila elpenor (Linnaeus, 1758), D. suellus Staudinger, 1878 (I follow the opinion of U. Eitschberger and V.V. Zolotukhin (1997) about its status), Hyles zygophylli (Ochsenheimer, 1808) and $H$. euphorbiae (Linnaeus, 1758).
One of these I treat as a migrant species for the Kyrgyz Republic: Rethera komarovi. It was recorded only once and the specimen was in a pretty bad condition (wings are threadbare; some parts of wings are absent, etc.).

Therefore, about $14 \%$ of the Kyrgyzstanian fauna of Sphingidae is represented by rare and local species: Sphingonaepiopsis kuldjaensis, Proserpinus proserpina, Hyles nicaea.

Sphingonaepiopsis kuldjaensis. It was collected only in an agricultural area near the dry lowlands at an altitude of $800-900 \mathrm{~m}$. This species is more characteristic of deserts and semideserts, so this record was quite interesting and even unexpected: the closest place where it was recorded is located 50-60 km northwards, in Kazakhstan (Kurdai Pass in the Chu-Ili mountains). This species, if it is not a temporal population, should be included into the Red Data Book of Kyrgyzstan.

Proserpinus proserpina. The only two collected specimens were absolutely fresh, so they cannot be considered as migrants. The biotope is dry mountain steppe with Artemisia sp. at an altitude of 900-1200 $\mathrm{m}$. The habitat preferences of this species are rather diverse: from the forest meadows to dry steppes. This is definitely a very rare species in this area; its distribution within Kyrgyzstan has been stated to lie within the limits of West Tian-Shan and in the Northern Kyrgyzstan (Milko, 1996). Without a doubt, it should be included in the Red Data Book of Kyrgyzstan. 
Table 1. Quantitative accounting results of hawkmoths of Kyrgyzstan

\begin{tabular}{|c|c|c|c|c|c|}
\hline № & Species / Localities & & $\begin{array}{l}\text { Total number } \\
\text { of specimens }\end{array}$ & $\begin{array}{c}\text { Trappings } \\
\text { amount }\end{array}$ & $\begin{array}{l}\text { Average specimens amount } \\
\text { within one trapping }\end{array}$ \\
\hline \multirow[t]{4}{*}{1} & Agrius convolvuli (Linnaeus, 1758) & & 364 & 90 & 4.04 \\
\hline & & Ala-Too & 120 & 30 & 4.30 \\
\hline & & Kok-Jar & 115 & 30 & 3.83 \\
\hline & & Sarban & 129 & 30 & 4.30 \\
\hline \multirow[t]{5}{*}{2} & Smerinthus kindermannii Lederer, 1852 & & 120 & 120 & 1.00 \\
\hline & & Archaly & 20 & 30 & 0.66 \\
\hline & & Karakol & 2 & 30 & 0.06 \\
\hline & & Kekemeren & 20 & 30 & 0.66 \\
\hline & & Koro-Goo & 78 & 30 & 2.60 \\
\hline 3 & Laothoe populi (Linnaeus, 1758) / Koro-Goo & & 30 & 10 & 3.00 \\
\hline 4 & Sphingonaepiopsis kuldjaensis (Graeser, 1892) / Kok-Jar & & 4 & 30 & 0.13 \\
\hline 5 & Rethera komarovi Christoph, 1885 / Sarban & & 1 & 30 & 0.03 \\
\hline 6 & Proserpinus proserpina (Pallas, 1772) / Ata-Too & & 2 & 30 & 0.06 \\
\hline \multirow[t]{3}{*}{7} & Theretra alecto (Linnaeus, 1758) & & 34 & 60 & 0.56 \\
\hline & & Ala-Too & 30 & 30 & 1.00 \\
\hline & & Archaly & 4 & 30 & 0.13 \\
\hline \multirow[t]{3}{*}{8} & Deilephila elpenor (Linnaeus, 1758) & & 121 & 60 & 2.02 \\
\hline & & Ata-Too & 50 & 30 & 1.66 \\
\hline & & Sarban & 71 & 30 & 2.36 \\
\hline \multirow[t]{4}{*}{9} & D. porcellus (Linnaeus, 1758) & & 340 & 90 & 3.77 \\
\hline & & Ala-Too & 100 & 30 & 3.33 \\
\hline & & Ala-Archa & 120 & 30 & 4.00 \\
\hline & & Archaly & 120 & 30 & 4.00 \\
\hline & D. suellus Staudinger, 1878 & & 90 & 120 & 0.75 \\
\hline & & Ala-Too & 5 & 30 & 0.16 \\
\hline & & Kekemeren & 25 & 30 & 0.83 \\
\hline & & Koro-Goo & 40 & 30 & 1.33 \\
\hline & & Urumbash & 20 & 30 & 0.66 \\
\hline & Hyles zygophylli (Ochsenheimer, 1808) & & 120 & 90 & 1.33 \\
\hline & & Ala-Too & 52 & 30 & 1.73 \\
\hline & & Sarban & 40 & 30 & 1.33 \\
\hline & & Ala-Archa & 28 & 30 & 0.93 \\
\hline & H. centralasiae Staudinger, 1887 & & 5 & 90 & 0.05 \\
\hline & & Archaly & 1 & 30 & 0.03 \\
\hline & & Kekemeren & 2 & 0 & 0.06 \\
\hline & & Koro-Goo & 2 & 30 & 0.06 \\
\hline & H. euphorbiae (Linnaeus, 1758) & & 62 & 120 & 0.52 \\
\hline & & Ala-Too & 22 & 30 & 0.73 \\
\hline & & Ala-Archa & 26 & 30 & 0.86 \\
\hline & & Karakol & 8 & 30 & 0.26 \\
\hline & & Kekemeren & 6 & 30 & 0.20 \\
\hline & H. nicaea (de Prunner, 1798) / Ala-Too & & 8 & 30 & 0.27 \\
\hline & H. gallii (Rottemburg, 1775) & & 623 & 120 & 5.20 \\
\hline & & Ala-Too & 320 & 30 & 10.66 \\
\hline & & Kok-Jar & 276 & 30 & 9.20 \\
\hline & & Karakol & 25 & 30 & 0.83 \\
\hline & & Urumbash & 2 & 30 & 0.06 \\
\hline & H. livornica (Rottemburg, 1775) & & 261 & 90 & 2.90 \\
\hline & & Ala-Archa & 200 & 30 & 6.66 \\
\hline & & Kekemeren & 12 & 30 & 0.40 \\
\hline & & Archaly & 49 & 30 & 1.63 \\
\hline
\end{tabular}

Hyles nicaea. The only eight specimens have been collected in Ala-Too; actually, in other parts of Kyrgyzstan, I collected this species as well, but these records were made without the quan- titative accounting. The species was collected in dry steppe zone at an altitude of 900-1800 m. Its inclusion in the Red Data Book of Kyrgyzstan requires re-assessment. 


\section{Discussion}

The Kyrgyzstanian fauna of Sphingidae comprises 22 species (Milko, 1996). I registered 16 of 18 species with nocturnal activity; Acosmeryx naga (Moore, 1857) was recorded as a definitely migrant species (loc. cit.) and was not recorded by me. Sphinx ligustri (Linnaeus, 1758) was on many occasions seen in flight but for some reason never visited my traps. The other Kyrgyzstanian hawkmoths are species with purely daytime activity, which are out of the subject of our paper: Hemaris ducalis (Staudinger, 1887), H. fuciformis (Linnaeus, 1758), H. tityus (Linnaeus, 1758) and Macroglossum stellatarum (Linnaeus, 1758).

As we can see from the "Results» chapter, only $18.2 \%$ of the whole hawk moths fauna of Kyrgyzstan represent most numerous species. Then, $18.2 \%$ of the fauna are rare species, $4.5 \%$ are migrants, and $31.2 \%$ are species with an average abundance. This shows almost the same results as previously found for butterflies (Manin, 1987, 2008): about $10-20 \%$ of the butterfly fauna represent most numerous species, the others are of an average abundance or rare.

It is very interesting to note that most of the rarest species according to our study are not exactly large or attractively coloured. In fact, Sphingonaepiopsis kuldjaensis is quite small and definitely not colourful (it is brown and grey with ochreous hind wings); Proserpinus proserpina is bright green but is also of a small size. Only Hyles nicaea is quite large, but its colouration is particularly bright either. Thus, the rarest species of hawkmoths of Kyrgyzstan are most unattractive.

Basing on this quantitative analysis I can propose the inclusion of two species of Sphingidae into the Red Data Book of Kyrgyzstan (Sphingonaepiopsis kuldjaensis and Proserpinus proserpina) and for one species additional research has to be conducted (Hyles nicaea). In fact, the latter was considered as a rare species in Middle Asia by many lepidopterists (in personal communications), but there are no published data about its abundance.

\section{Acknowledgements}

I am grateful to the following persons who accompanied me during my trips in Kyrgyzstan in 2015-2017: A. Nikolaev (Cherepovets, Russia), J. Packalen (Helsinki, Finland), A. Samus (Volgograd, Russia), A. Belik (Saratov, Russia), E. Komarov and O. Komarova (Volgograd, Russia), V. Korb (Vetluzhsky, Russia). I am very thankful to V. Proklov (London, UK) for linguistic corrections of this paper.

\section{References}

Beck J., Linsemair K.E. 2006. Feasibility of light-trapping in community research on moths: Attraction radius of light, completeness of samples, nightly flight times and seasonality of Southeast-Asian hawkmoths (Lepidoptera: Sphingidae). Journal of Research on the Lepidoptera 39: 18-37.

Bogush P.P. 1951. The usage of the light traps as an method of the strength dynamics of insects. Entomological Review 31(3-4): 605-628. [In Russian]

Derzhavets Yu.A. 1984. An account of the classification of the Sphinx moths (Lepidoptera, Sphingidae) with a list of species of the fauna of the USSR. Entomological Review 63(3): 604-620. [In Russian]

Duarte J.A. Jr., Schlindwein C. 2008. Hawkmoth fauna of a Northern Atlantic rain forest remnant (Sphingidae). Journal of the Lepidopterologists 'Society 62(2): 71-79.

Dubatolov V.V. 2012. The usage of the light traps for the abundance estimation of the nocturnal Lepidoptera (Insecta). Euroasian Entomological Journal 11(2): 186-188.

Eitschberger U., Zolotukhin V.V. 1997. Choerocampa suellus sibirica nom. nov. et comb. nov. pro Pergesa porcellus porca O. Bang-Haas, 1927 (Lepidoptera, Sphingidae). Atalanta 28(1/2): 145.

Gornostaev G.N. 1961. A construction of the light traps for the nocturnal insects collecting. Herald of Moscow University 4: 54-57. [In Russian]

Kaila L., Viidalepp J., Mikkola K., Mironov V. 1996. Geometridae (Lepidoptera) from the Tian-Shan mountains in Kazakhstan and Kyrgyzstan, with descriptions of three new species and one new subspecies. Acta Zoologica Fennica 200: 57-82.

Korb S.K. 2012. Butterflies (Lepidoptera: Papilionoformes) of the North Tian-Shan. Part 1. Families Hesperiidae, Papilionidae, Pieridae, Libytheidae, Satyridae. Eversmannia Suppl. 3: 1-84. [In Russian]

Korb S.K. 2013. Butterflies (Lepidoptera: Papilionoformes) of the North Tian-Shan. Part 2. Families Nymphalidae, Riodinidae, Lycaenidae. Eversmannia Suppl. 4: 1-74. [In Russian]

Korb S.K. 2015. Butterflies (Lepidoptera: Papilionoformes) of Inner Tian-Shan. Identification keys and reference book. Eversmannia Suppl. 6: 1-84. [In Russian]

Korb S.K. 2017. Butterflies of Central Tian-Shan (Lepidoptera: Papilionoformes). Eversmannia 49: 24-49. [In Russian]

Korb S.K., Matov A.Y., Pliushch I.G., Klyuchko Z.F., Poltavsky A.N. 2016. The Noctuoid moths of Kyrgyzstan. Moscow: KMK Scientific Press, Ltd. 230 p.

Manin B.L. 1987. Results of the quantitative accounting of butterflies within the mountains of Kazakhstan and Kyrgyzstan. In: Butterflies of USSR. Proceedings of the meeting «Systematics, faunistics, ecology, protection of butterflies» (2-5 October 1987). Novosibirsk: Nauka. P. 79-80. [In Russian]

Manin B.L. 2008. The results of the comparative censuses of Lepidoptera, Rhopalocera in the mountains of Kazakhstan. In: Landscape zoogeography and zoology. Moscow: MOIP Publishing House. P. 105-120. [In Russian] 
Matalin A.V. 1996. On the usage of the light traps for the ecological studies of Carabidae (Coleoptera). Zoologicheskii Zhurnal 75(5): 744-756. [In Russian]

Mazokhin-Porshnyakov G.A. 1958. The construction and usage of the insect traps equipped with UV-light source. Entomological Review 37(2): 464-471. [In Russian]

Milko D. 1996. Lepidoptera. In: Cadastre of the genetic diversity of Kyrgyzstan. Bishkek: Ecological Association «Alejne». P. 209-260. [In Russian]
Schintlmeister A. 2008. Palaearctic Macrolepidoptera. Vol. 1. Notodontidae. Stenstrup: Apollo Books. 482 p.

Tshikolovets V.V. 2005. The butterflies of Kyrgyzstan. Kyiv, Brno: Tshikolovets Publications. 511 p.

Vieira K.C.R., de Souza Moraes S., Chiquetto-Machado P.I., Duarte M. 2015. Crepuscular and nocturnal hawkmoths (Lepidoptera: Sphingidae) from a fragment of Atlantic rainforest in the state of São Paulo, southeastern Brazil. Florida Entomologist 98(1): 342-348.

\title{
АВТОМАТИЧЕСКИЕ АВТОНОМНЫЕ СВЕТОВЫЕ ЛОВУШКИ И ИХ ИСПОЛЬЗОВАНИЕ ДЛЯ КОЛИЧЕСТВЕННОГО АНАЛИЗА НА ПРИМЕРЕ БРАЖНИКОВ КИРГИЗИИ (LEPIDOPTЕRA: SPHINGIDAE)
}

\author{
С. К. Корб \\ Русское энтомологическое общество, Нижегородское отделение, Россия \\ e-mail:stanislavkorb@list.ru
}

\begin{abstract}
Представлены данные количественных учетов бражников Киргизии с использованием автоматических автономных световых ловушек. Было зарегистрировано 16 видов бражников с ночной активностью, четыре являются массовыми, восемь - со средней численностью, один определен как мигрант и три - редкие. Два вида предлагаются для включения в Красную книгу Республики Кыргызстан (Sphingonaepiopsis kuldjaensis, Proserpinus proserpina).
\end{abstract}

Ключевые слова: Sphingidae, бражники, количественный анализ, Красная книга Киргизии, световые ловушки 